\title{
Bacterial and parasitic zoonoses encountered at slaughter in Maiduguri abattoir, Northeastern Nigeria
}

\author{
Adamu Nuhu Bala ${ }^{1}$, Ali Emmanuel Garba ${ }^{1}$, Adamu James Yazah²* \\ 1. Department of Veterinary Public Health and Preventive Medicine, \\ 2. Bacteriology Research Unit, Department of Veterinary Microbiology and Parasitology, \\ University of Maiduguri, PMB 1069, Maiduguri, Borno State, Nigeria. \\ Corresponding author email: adamuyaz@yahoo.com \\ Received: 18-05-2011, Accepted: 28-05-2011, Published Online: 05-09-2011
}

doi: $10.5455 /$ vetworld.2011.437-443

\begin{abstract}
An abattoir survey to determine the prevalence of zoonotic diseases encountered at postmortem examination of organs and carcasses was conducted in Maiduguri municipality, Nigeria, between 2000 and 2009. A total of 1,378,066 animals were examined and slaughtered from which 403,560 were cattle, 381,601 goats, 373,567 sheep and 219,308 camels. Out of these numbers, a total of 14,944 bacterial and parasitic zoonotic diseases were diagnosed which included tuberculosis $(67.6 \%)$, dermatophilosis $(15.8 \%)$, mange $(16.7 \%)$, fascioliasis $(1.5 \%)$ and hydatidosis $(4.3 \%)$. Occurrence of the diseases based on sex, species of animals and season of the year did not show any significant difference $(\mathrm{P}>0.05)$. It was not possible to get the exact records on breed and age for each slaughtered animal due to poor recording systems at the abattoir. With regards to the type of animals brought for slaughter, almost all animals come from the traditional sector and it was difficult to precisely trace back the geographical origins of all animals slaughtered due to lack of reliable animal identification method and so relating the finding of the study to a particular locality becomes difficult. Species-specific prevalence of tuberculosis was $1.6 \%, 0.4 \%, 0.3 \%, 0.3 \%$ for cattle, sheep, goats and camels respectively with a $0.7 \%$ crude prevalence. Analysis of the tuberculosis cases showed a high rate of occurrence in cattle $(\mathrm{P}<0.05)$ and the most affected organs were the lungs $(55.1 \%)$ and associated lymph nodes $(27.7 \%)$ $(\mathrm{P}<0.05)$. It was concluded that zoonotic diseases such as tuberculosis, dermatophilosis and mange are endemic in the study area. Abattoir records are invaluable in epidemiological surveillance and other aspects of disease control and prevention strategies.
\end{abstract}

Keywords: Zoonoses, Ruminants, Abattoir, Survey, Maiduguri, Tuberculosis, Fascioliasis, Hydatidosis, Postmortem, Dermatophilosis.

\section{I ntroduction}

Nigeria has the largest number of livestock population in the West African sub-region and about $11.6 \%$ of the livestock population are in sub-Saharan Africa (FAO, 2000). The country has a livestock population of about 16.3 million cattle, 40.8 million goats, 27 million sheep, and 151 million poultry (http://www.africanagricultureblog.com/2007/12/nig eria-has-16-million-cattle.html). Livestock and poultry production are the main economic activities of about $70 \%$ of Nigerians living in rural and urban areas. There is increasing contact between humans and animals worldwide due to rising population density and growth especially in developing countries where livestock offers important socio-economic, cultural and religious pathways out of poverty (WHO, 2004). However, food animal production has become a strategic subsector for diversification of income and the fight against malnutrition and unemployment in the urban and rural areas of the world (Tanya et al., 2004).

High prevalence of animal diseases affects both health and productivity of livestock population. As a result of devastating outcome of livestock diseases, animal protein output has not been able to keep up with the nation's demands (Njombe and Msanga, 2009). Increasing demand for meat and meat product by human population has made human contact with animals unprecedented, coupled with movement of animals across international frontiers to supplement the local supply and increasing the risk of zoonotic diseases especially from endemic zones (Shcwabe, 1984).

The control of livestock diseases still remains a problem because of inadequacy of veterinary services extended to livestock owners particularly those in the rural areas (Kambarage et al., 1995). This may 
contribute to a widespread prevalence of diseases in traditional sector (Mellau et al., 2010). Some livestock owners dispose sick, debilitated and infertile animals in an effort to minimize losses. Such animals sometimes are brought to the abattoir for slaughter while some are slaughtered elsewhere. In developing countries, abattoirs and slaughter slabs have poor meat inspection facilities and shortage of qualified meat inspectors (Edwards et al., 1997; Biu et al., 2006) and may serve as focal points for disease dissemination. The slaughterhouse and its regulations, represents a key control point of livestock production chain (Raji et al., 2010) and any observation and information obtained at slaughterhouse can contribute to the understanding of slaughtered animals' diseases. Slaughterhouses provide an excellent opportunity for detecting diseases of both economic and public health importance (Raji et al., 2010). Therefore, the use of meat inspection records is an easy source of data for evaluation of epidemiological aspects of animal diseases (Edwards et al., 1997; Schweizer et al., 2003). This study is therefore aimed at investigating the prevalence of some zoonotic diseases in Maiduguri during a 10-year period (2000-2009).

\section{Materials and methods}

The study area: The study was carried out in Maiduguri, the capital and largest urban center in Borno State, Nigeria. The state lies between latitude $11^{\circ} 05^{\prime} \mathrm{N}$ and $11^{\circ} 40 \mathrm{~N}$ and longitude $13^{\circ} 05^{\prime} \mathrm{E}$ and $13^{\circ} 25^{\prime}$ E (Mbaya et al., 2008). The state has a total area of $72,609 \mathrm{sq} . \mathrm{km}$ and is the largest of 36 states in Nigeria in terms of landmass and has a human population of 4,151,193 based on 2006 census (NBS, 2011). The state has a total Gross Domestic Product (GDP) of about US\$5.18 billion and a per capita income of US $\$ 1,214$. The state is bordered by three francophone countries namely Niger, Chad and Cameroon (https://www.cgidd.com/Geography-Selection.aspx). Borno State has a relatively short rainy season starting in June and ending in October, and a longer dry season with the harmattan starting in November and ending in February. The average monthly temperature of Maiduguri is $35^{\circ} \mathrm{C}$, however, during the cooler periods (November-February) the average temperature drops to about $20{ }^{0} \mathrm{C}$ (http://www.climate-charts.com/ Locations/n/NI65082.php).

Data retrieval, collation and procedures: The Maiduguri central abattoir was selected for the study and is under the supervision of Ministry of Animal and Forest Resources of the Borno State Government. Permission was obtained from the relevant authority.
Qualified veterinarians serve as meat inspectors under the supervision of Veterinary Surgeon as officer in charge. Records of total number of cattle, sheep, goats and camels brought for slaughter, antemortem and postmortem examination records of lesions were retrieved from Maiduguri abattoir record books. Such records were used to establish the prevalence of bacterial and parasitic zoonotic diseases and lesions affecting cattle, sheep, goats, and camels. Routinely, meat inspectors carry out antemortem examinations of all animals presented for slaughter a day before or shortly prior to slaughter. This is followed by postmortem meat inspection involving visual examination, palpation and systematic incision of carcasses and visceral organs particularly lung, liver, kidney, heart and spleen according to procedures described by Gracey et al. (1999). Diseases and lesions are grossly diagnosed based on pathological changes of organ colour, size, morphology, consistency, presence of lesions and parasites (Mellau etal., 2010).

Definition of some conditions encountered in this study: Tuberculosis is a contagious and usually a chronic debilitating disease in animals and man caused by a bacterium in the genus Mycobacterium spp. which pathologically is characterized by tubercule formation in the lungs and associated lymph nodes. The disease can be spread hematogenously to other organs of the body.

Dermatophilosis (Streptothricosis) is a skin disease caused by a bacterium called Dermatophilus congolensis. The condition is sometimes referred to as "rain scald" as it often looks like raindrops have just fallen on the skin. The condition is initially seen as pustules that are often over-looked. However, the pustules quickly come to together to form large oval crusts as the longer hairs become stuck together in the scab. These large crusty scabs are easily seen. Thick, creamy pus can be found under active crusts. When the scabs or crusts are removed, the underlying skin is usually hollowed out and often bleeds. Most animals do not appear to have itching sensation, however, the lesions are painful when the scab is manipulated. The most common locations of the lesions in cattle are rump, topline, udder and teats as well as the belly.

Mange is a persistent contagious skin disease of mammals caused by a tissue-burrowing arthropod, the mange mite causing a lot of skin irritation and itching.

Hydatidosis or echinococcosis is a parasitic infection caused by the larvae of a microscopic tapeworm of genus Echinococcus. The term hydatid refers to the characteristic multicystic lesion a large, roughly spherical, hollow cyst filled with fluid that 
Bacterial and parasitic zoonoses encountered at slaughter in Maiduguri abattoir, Northeastern Nigeria

Table-1. Annual distribution of bacterial and parasitic zoonotic diseases among slaughtered animals in Maiduguri abattoir from 2000-2009.

\begin{tabular}{|c|c|c|c|c|c|c|c|c|c|c|c|c|}
\hline Diseases & 2000 & 2001 & 2002 & 2003 & 2004 & 2005 & 2006 & 2007 & 2008 & 2009 & Total & Percentage \\
\hline Dermatophilosis & 265 & 279 & 232 & 280 & 190 & 164 & 208 & 176 & 169 & 254 & 2217 & $14.84^{b}$ \\
\hline Mange & 111 & 143 & 472 & 408 & 341 & 302 & 261 & 0 & 171 & 136 & 2345 & $15.69^{b}$ \\
\hline Fascioliasis & 20 & 16 & 16 & 25 & 21 & 26 & 30 & 23 & 29 & 23 & 229 & $1.53^{c}$ \\
\hline Hydatidosis & 29 & 60 & 110 & 88 & 57 & 63 & 51 & 61 & 57 & 68 & 644 & $4.31^{\circ}$ \\
\hline Total & 820 & 862 & 1230 & 1256 & 1908 & 1863 & 2128 & 1109 & 1976 & 1792 & 14944 & \\
\hline Percentage & 5.48 & 5.76 & 8.23 & 8.40 & 12.76 & 12.46 & 14.23 & 7.42 & 13.22 & 11.99 & 100 & \\
\hline
\end{tabular}

Values with different superscript along the column differ significantly $(P<0.05)$

occurs after infection. It affects both humans and other mammals, such as sheep, dogs, rodents and horses. There are three different forms of echinococcosis, each of which is caused by the larval stages of different species of the tapeworm of genus Echinococcus. These are the cystic echinococcosis also known as unilocular echinococcosis), which is caused by Echinococcus granulosus. The second is alveolar echinococcosis (also known as alveolar colloid of the liver, alveolar hydatid disease, alveolococcosis, multilocular echinococcosis, "small fox tapeworm"), which is caused by Echinococcus multilocularis and the third is polycystic echinococcosis (also known as human polycystic hydatid disease), which is caused by Echinococcus vogeli.

Fascioliasis is an infectious disease caused by Fasciola parasites, which are flat worms referred to as liver flukes. The adult (mature) flukes are found in the bile ducts and liver of infected people and animals, such as sheep and cattle. In general, fascioliasis is more common in livestock and other animals than in people.

Data analysis: The data for this study were analyzed using simple descriptive statistics in excel spreadsheet. Categorized variables were computed and further compared using Chi-square test at critical probability of $\mathrm{P}<0.05$. The strength of associations between dependent and independent variables was determined using $2 \times 2$ contingency tables. The variables compared included prevalence of the diseases based on years, species of animal, sex and season. Organspecific prevalences of tuberculosis lesions were also compared.

\section{Result}

A total of $1,378,066$ animals comprising of $403,560(29.3 \%)$ cattle, 381,601 (27.7\%) goats, $373,567(27.1 \%)$ sheep and 219,308 (16.0\%) camels were examined, slaughtered and inspected between January 2000 and December 2009. Annual distribution of the bacterial and parasitic zoonotic diseases is shown in Table 1 . The result showed that a total of 14,944 bacterial and parasitic zoonotic diseases were encountered which comprised of 9,509 cases of tuberculosis $(67.6 \%), 2,217$ dermatophilosis $(15.8 \%), 2,345$ cases of mange (16.7\%), 644 cases of hydatidosis $(4.3 \%)$ and 229 cases of fascioliasis (1.5\%) with tuberculosis occurring more significantly than others $(\mathrm{P}<0.05)$. Fascioliasis was encountered mainly in cattles while hydatidosis was encountered majorly in the other animal species under consideration. The sex-specific prevalence of the zoonotic diseases encountered is shown in Table 2.

Table-2. Occurrence of the diseases based on sex

\begin{tabular}{llll}
\hline Diseases & Males & Females & Total \\
\hline Tuberculosis & 5389 & 4120 & 9509 \\
Dermatophilosis & 1287 & 930 & 2217 \\
Mange & 1090 & 1255 & 2345 \\
Fascioliasis & 101 & 128 & 229 \\
Hydatidosis & 346 & 298 & 644 \\
Total & 8213 & 6731 & 14944 \\
\hline
\end{tabular}

On the basis of seasonality, more cases were recorded in the raining season than the dry and cold harmattan seasons as seen in Table 3 but not statistically significant $(\mathrm{P}>0.05)$. Detailed analysis of the tuberculosis cases are shown in Table 4 with cattle, goats, sheep and camels having prevalences of $1.6 \%$, $0.25 \%, 0.4 \%$, and $0.33 \%$ respectively. Organ-specific prevalence of tuberculosis in the slaughtered animals showed that the lungs and associated lymph nodes were affected more significantly than the other organs as shown in Table 5. Prevalence of tuberculosis between cattle and other species varied significantly but not across the years. The trend of tuberculosis infection in the animals showed a rising and falling pattern across the years.

\section{Discussion}

Slaughter houses provide an excellent opportunity for detecting diseases of both economic and public health importance (Raji et al., 2010). Frequent encounter of bovine, caprine and ovine 
Table-3. Seasonal distribution of bacterial and parasitic zoonotic diseases among slaughtered animals in Maiduguri Abattoir (2000-2009).

\begin{tabular}{lllllllllllll}
\hline Seasons & $\mathbf{2 0 0 0}$ & $\mathbf{2 0 0 1}$ & $\mathbf{2 0 0 2}$ & $\mathbf{2 0 0 3}$ & $\mathbf{2 0 0 4}$ & $\mathbf{2 0 0 5}$ & $\mathbf{2 0 0 6}$ & $\mathbf{2 0 0 7}$ & $\mathbf{2 0 0 8}$ & $\mathbf{2 0 0 9}$ & Total & Percentage \\
\hline Dry season & 381 & 472 & 512 & 574 & 423 & 388 & 386 & 364 & 384 & 480 & 4364 & $29.20^{\text {a }}$ \\
Rainy season & 459 & 421 & 522 & 610 & 597 & 405 & 579 & 405 & 643 & 556 & 5197 & $34.77^{\text {a }}$ \\
Cold season & 600 & 391 & 560 & 566 & 565 & 604 & 501 & 419 & 621 & 556 & 5383 & $36.03^{\text {a }}$ \\
Total & 1440 & 1284 & 1594 & 1750 & 1585 & 1397 & 1466 & 1188 & 1648 & 1592 & 14944 & \\
\hline
\end{tabular}

Values with superscript along the column do not differ significantly $(P>0.05)$

pathological lesions in various organs of the animal has been constant features in the annual reports of various government stations in Nigeria (Babalola, 1975; Ogurinade and Ogunrinade, 1980; Antia and Alonge, 1982). The results of this study showed that about 1,378,066 animals were examined and slaughtered in the Maiduguri abattoir which comprised of $29.3 \%$ cattle, $27.6 \%$ goats, $27.1 \%$ sheep and $16.0 \%$ camels. A total of 14,944 bacterial and parasitic zoonotic diseases were encountered which included tuberculosis, dermatophilosis mange, hydatidosis and fascioliasis with prevalence rate of $67.5 \%, 15.7 \%, 16.7 \%, 4.3 \%$ and $1.5 \%$ respectively, with tuberculosis being encountered more than the other diseases $(\mathrm{P}<0.05)$.

The presence of these zoonotic diseases has also been reported previously by Opara (2005), Aliyu et al. (2009), Raji et al. (2010), and Alawa et al. (2011). Analysis of the sex prevalence of the diseases did show that, generally, males were affected more than the females but not statistically significant, likewise in terms of disease specificity, males were affected more but not significantly. Such difference may occur by chance or may be due to difference in genetic makeup in terms of sexual predisposition. Blood et al. (2007) has earlier reported higher prevalence of tuberculosis among female cattle than their male counterparts. Seasonality did not have much influence on the outcome of the study even though more cases were recorded during the raining season. Opara (2005) reported more cases of tuberculosis during the rainy season which contrasted that of Alhaji (1976) who recorded higher prevalence of the disease during the dry season.

Among the diseases of cattle, sheep and goats, infestation by mange mites and ticks, as well as dermatophilosis pose a considerable economic loss particularly to the skin and hide export due to various defects (Woldemeskel, 2000). In Nigeria, the economic significance of dermatophilosis in animals had reached an enormous proportion such that it was declared as second to contagious bovine pleuropneumonia (Llyod and Ojo, 1976). Though mites are active in keratin layer and causes direct damage to skin, they also cause indirect economic loss by decreasing/ceasing reproduction and production performance (Soulsby, 1998). Dermatophilosis has been diagnosed in man in New York, and surveillance is necessary to establish the zoonotic status of the infection in Nigeria. The organism requires existing skin lesions to establish infection, so people with skin lesions are at higher risk especially herdsmen, farmers, veterinarians and butchers who make direct contact with infected animals (Ikpeze, 2004).

Fascioliasis which is caused by the trematode Fasciola spp. constitute both economic and public health constrains to profitable ruminant production in tropical Africa (Fabiyi and Adeleye, 1982).

Table-4. Prevalence of tuberculosis lesions among animals slaughtered at the Maiduguri abattoir from 2000-2009.

\begin{tabular}{|c|c|c|c|c|c|c|c|c|c|c|c|c|}
\hline Species & Particulars & 2000 & 2001 & 2002 & 2003 & 2004 & 2005 & 2006 & 2007 & 2008 & 2009 & Total \\
\hline \multirow{3}{*}{ Bovine } & No. examined & 12458 & 31906 & 47483 & 44350 & 40372 & 47331 & 46781 & 45761 & 43977 & 43141 & 403560 \\
\hline & No. with TB & 329 & 270 & 225 & 249 & 702 & 890 & 878 & 663 & 1139 & 1023 & 6368 \\
\hline & Prevalence (\%) & 2.64 & 0.85 & 0.47 & 0.56 & 1.74 & 1.88 & 1.88 & 1.45 & 2.59 & 2.37 & $1.58^{\mathrm{a}}$ \\
\hline Caprine & Prevalence (\%) & 0.09 & 0.08 & 0.26 & 0.13 & 0.66 & 0.37 & 0.32 & 0.07 & 0.43 & 0.08 & $0.28^{\mathrm{b}}$ \\
\hline \multirow[t]{3}{*}{ Ovine } & No. examined & 33281 & 38412 & 35589 & 33922 & 36888 & 40791 & 37896 & 38456 & 40067 & 38265 & 373567 \\
\hline & No. with TB lesions & 7 & 28 & 50 & 131 & 286 & 247 & 397 & 4 & 105 & 168 & 1423 \\
\hline & Prevalence (\%) & 0.02 & 0.07 & 0.14 & 0.39 & 0.78 & 0.61 & 1.05 & 0.01 & 0.26 & 0.44 & $0.38^{\mathrm{b}}$ \\
\hline Camel & Prevalence (\%) & 0.16 & 0.20 & 0.11 & 0.13 & 0.21 & 0.10 & 1.11 & 0.61 & 0.50 & 0.23 & $0.33^{\mathrm{b}}$ \\
\hline \multirow[t]{3}{*}{ All } & No. examined & 98626 & 127812 & 141296 & 137084 & 136552 & 149020 & 138505 & 145152 & 146853 & 157166 & 1378066 \\
\hline & No. with TB lesions & 395 & 364 & 400 & 455 & 1299 & 1308 & 1578 & 869 & 1530 & 1311 & 9509 \\
\hline & Prevalence (\%) & 0.40 & 0.28 & 0.28 & 0.33 & 0.95 & 0.88 & 1.14 & 0.59 & 1.04 & 0.83 & $0.33^{b}$ \\
\hline
\end{tabular}

Values with different superscript along the column differ significantly $(P<0.05)$ 
Bacterial and parasitic zoonoses encountered at slaughter in Maiduguri abattoir, Northeastern Nigeria

Table-5. Organ-specific occurence of tuberculosis among slaughtered animals in Maiduguri abattior from 2000-2009.

\begin{tabular}{|c|c|c|c|c|c|c|c|c|c|c|c|c|}
\hline Organs & 2000 & 2001 & 2002 & 2003 & 2004 & 2005 & 2006 & 2007 & 2008 & 2009 & Total & Percentage \\
\hline Lungs & 650 & 540 & 469 & 515 & 552 & 447 & 503 & 475 & 541 & 548 & 5240 & $55.10^{a}$ \\
\hline Lymph node & 96 & 192 & 333 & 447 & 319 & 349 & 240 & 102 & 338 & 219 & 2635 & $27.71^{b}$ \\
\hline Liver & 28 & 47 & 11 & 62 & 29 & 52 & 120 & 116 & 33 & 31 & 529 & $5.55^{c}$ \\
\hline Kidney & 31 & 21 & 8 & 16 & 10 & 22 & 11 & 28 & 21 & 8 & 176 & $1.85^{\circ}$ \\
\hline Spleen & 21 & 28 & 6 & 16 & 36 & 31 & 44 & 29 & 37 & 5 & 253 & $2.56^{\circ}$ \\
\hline Intestine & 30 & 30 & 46 & 77 & 40 & 35 & 29 & 40 & 25 & 46 & 398 & $4.19^{c}$ \\
\hline
\end{tabular}

Values with different superscript along the column differ significantly $(P<0.05)$

Fascioliasis affects the liver leading to liver condemnation in slaughtered animals. The overall prevalence in this study was $1.5 \%$ which is lower than those reported by Njoku-Tony and Okoli (2011), Abebe et al. (2010), Swai and Ulicky (2009), Kithuka et al. (2002), Okoli et al. (2000) and Alonge and Fasami (1979). Differences in prevalence of fascioliasis may arise due to poor meat inspection facilities and uncooperative attitudes of butchers because of lack of compensation of condemned organs, seasonality and differences in geographical locations in relation to the bionomics of their snail intermediate host (Anosike et al., 2001). Hydatidosis is a parasitic zoonotic disease caused by the metacestode stage of the dog tapeworm Echinococcus spp. A prevalence of $4.3 \%$ in this study was higher when compared with the $0.1 \%$ reported by Tijjani et al. (2010) in small ruminants in the same region. Hydatidosis is associated with livestock morbidity and mortality, organ and meat condemnation at inspection and threat to public health as a result of the close association between dogs, food animals and man.

Detailed analysis of tuberculosis among the slaughtered animals shows that cattle had the overall highest prevalence rate of $1.6 \%$ which is significantly different from those of the other animal species in the study. The prevalence across the years was not significant. Prevalence of tuberculosis among animal slaughtered in abattoir has been reported by many authors. The overall prevalence of tuberculosis in this study is $0.7 \%$. Higher prevalence rate of $4.05 \%$ was reported by Aliyu et al.(2009) from cattle in six northern states of Nigeria; 3.4\% by Opara (2005) from cattle in Akwa Ibom state; $9 \%$ by Maho et al. (1999) from cattle in Chad. Lower prevalence rates of $0.01 \%$ and $0.08 \%$ were also reported by Alawa et al. (2011) and Ojo (1996) respectively in Zaria. Organ specific prevalence of tuberculosis did showed that the lungs were mostly affected $(\mathrm{P}<0.05)$ as compared to the other organs followed by the lymph nodes. This further confirms that the primary organ of infection of tuberculosis is the respiratory system and associated lymph nodes. This is in concordance with the reports of Igbokwe et al. (2001) and Liebana et al. (2008). Even though not a novel finding per se, the affirmation of such detail is important in the overall context of disease surveillance and monitoring (Cassidy, 2008). Trend of the occurrence of tuberculosis among the different animal species in this study showed a rising and falling pattern which suggests that tuberculosis among animal populations in this part of the world is still endemic. Endemic nature of zoonotic diseases in the area of study could be due to the lack of proper management of animals against important zoonotic diseases, failure to adopt the test and slaughter policy in Nigeria and the influx of infected animals from neighboring countries due to the porosity of our borders (Aliyu et al., 2009).

\section{Conclusion}

The prevalence of zoonotic diseases such as tuberculosis, dermatophilosis, mange, fascioliasis and hydatidosis contribute to organ condemnation associated with economic loss. Results of this study reveals that these diseases are endemic in the study area. Retrospective study of diseases encountered at abattoir will provide useful pathology profiles which could be useful in future risk assessment and planning of control and prevention strategies. It is therefore recommended that retraining of abattoir staff on modern methods of meat inspection practices be done. This suggests a need for a rigorous meat inspection procedure to minimize the chance of consumers acquiring infection through contact with and/or consumption of infected meat. Proper record keeping of abattoir data and if possible computerization of such data is necessary. Public enlightenment campaigns on good livestock husbandry practices at local and national levels should be encouraged.

\section{Acknowledgements}

The authors are grateful to the Ministry of 
Animal and Forest Resources, Maiduguri and the Veterinarians at the Maiduguri Central Abattoir for their help and assistance.

\section{References}

1. Abebe R., Abunna F., Berhane M., Mekuria S., Megersa B. and Regassa A. (2010). Fasciolosis: prevalence, financial losses due to liver condemnation and evaluation of a simple sedimentation diagnostic technique in cattle slaughtered at Hawassa Municipal abattoir, Ethiopia. Ethiop. Vet. J. 14(1): 39-51.

2. Alawa C.B., Etukudo-Joeseph I., Alawa J.N. (2011). A 6year survey of pathological conditions of slauthered animals at Zongo abattoir in Zaria, Kaduna State, Nigeria. Trop. Anim. Health Prod. 43(1):127-31.

3. Alhaji I. (1976). Bovine tuberculosis: A general view with special reference to Nigeria. Vet. Bull. 46:829-841.

4. Aliyu M.M., Adamu J.Y., Bilyaminu Y.A. (2009). Current prevalence of tuberculous lesions among slaughtered cattle in Northeastern States of Nigeria. Revue Elev. Med. Vet. Pays trop. 62(1):13-16.

5. Alonge D.O. and Fasami E.F. (1979). A survey of abattoir data in Northern Nigeria. Trop. Anim. Health Prod.1: 57-62.

6. Anosike J.C., Okafor F.C. and Mbata G. (2001). Studies on Paraamphistomum cervi infection in ruminants in Imo State. Bull. Anim. Hlth. Prod.Afr. 23(3): 289.

7. Antia R.E. and Alonge D.O. (1982). Survey of abattoir data in Southern Nigeria. Trop. Anim. Health Prod.14(2):119-120.

8. Babalola D.A. (1975). Diseases of thoracic organs associated with slaughtered cattle in Bauchi abattoir Northeastern State of Nigeria. J. Nigerian Vet. Med. Assoc. 4(1): $37-40$.

9. Blood D.C., Radostits O.M., Gay C.C., Hinchcliff K.W. and Constable P.D. (2007). Veterinary Medicine: A textbook of the Diseases of Cattle, Horses, Sheep, Pigs, and Goats, 10th ed. Saunders Ltd, pp 2065.

10. Biu A.A., Ahmed M.I., Mshelia S.S. (2006). Economic assessment of losses due to parasitic diseases at the Maiduguri abattoir, Nigeria. Afr. Scientist, 7:143-145.

11. Cassidy J.P., (2008). The pathology of bovine tuberculosis: Time for audit. Vet. Rec. 176:263-264.

12. Edwards D.S., Johnson A.M., Mead G.C. (1997). Meat inspection: an overview of present practices and future trends. Vet. J. 154:135-147.

13. Fabiyi J.P. and Adeleye G.A. (1982). Bovine fascioliasis on the Jos Plateau, Northern Nigeria. Bull. Anim. Health and Prod. Afr. 30(1): 41-43.

14. FAO, (2000). Appendix 3. Livestock population in subSaharan Africa, 1999. FAOSAT 2000 (www.fao.org) DOCREP/005/Y4176E/y4176eOf.htm)

15. Gracey J.F., Collins D.S., Huey R.J. (1999). Meat hygiene, 10th ed. W.B. Saunders Company,Ltd, pp 261-287.

16. Igbokwe I.O., Madaki I.Y., Danburam S., Ameh J.A., Aliyu M.M., Nwosu C.O. (2001). Prevalance of pulmonary tuberculosis lesion in cattle slaughtered in abattoirs in Northerneastern Nigeria. Revue Elev. Med. Vet. Pays trop., 54:191-195.

17. Ikpeze O.O (2004). Dermatophilosis infection in Nigeria: a mini review. Bio-Research, 2(2): 37-41.

18. Kambarage D.M., Kimera S.I., Kazwala R.R., Mafwere B.M. (1995). Disease conditions responsible for condemnation of carcasses and organs in short-horn Zebu cattle slaughtered in Tanzania. Prev. Vet. Med. 22:249-255.

19. Kithuka J.M., Maingi N. and Njeruh F.M. (2002). The prevalence and economic Importance of bovine fascioliasis in Kenya: an analysis of abattoir data. Ondestepoort J. Vet. Res. 69(4): 255-262.

20. Liebana E., Johnson L., Gough J., Durr P., Jahansk., Cliffton-Hadley R., Spencer Y., Hewinson R.G., Down S.H (2008). Pathology of naturally occurring bovine tuberculosis in England and Wales. Vet. Rec., 176:354-360.

21. Lloyd D.H. and Ojo M.O. (1976). Streptothricosis in domestic donkey (Equus asinus asinus) II. Bacteriology and immunological relationships of the strains of Dermatophilus congolensis isolated. Br. Vet. J., 131:108-114.

22. Maho A., Mbakasse R.N., Boulbaye N. (1999). Causes de saisies aux abattoirs du Tchad oriental. LRVZ/F in: Actes 3 journees agro-sylvopastorales, Laborotoires de recherches veterinaires et zootechniques de Farcha, N'Djamena, Tchad, 29 nov.-3 dec. 1997.

23. Mbaya A.W., Aliyu M.M., Nwosu C.O., Ibrahim U.I. (2008) Captive wild animals as potential reservoirs of haemo and ectoparasitic infection of man and domestic animals in the arid-region of Northeastern Nigeria. Vet. Arhiv. 78:429-40.

24. Mellau, L.S.B., Nonga H.E. and Karimuribo E.D. (2010). A slaughter survey of lung lesions in slaughtered stocks at Arusha, Tanzania. Prev. Vet. Med. 97:77-82.

25. Nigerian Bureau of Statistics (NBS) (2011). Federal Republic of Nigeria 2006 population census. Official Gazatte (FGP 71/52007/2,500(OL24). http://www. nigerianstat.gov.ng/ (accessed 18/05/2011).

26. Njombe A.P. and Msanga Y.N. (2009). Livestock and Dairy Industry Development in Tanzania. http://www.mifugo. go.tz (accesses 06/04/10).

27. Njoku-Tony R.F. and Okoli G.C. (2011). Prevalence of fascioliasis among slaughter sheep in selected abattoirs in Imo State, Nigeria. J. American Sci. 7(2): 361-366 .

28. Ogurinade A. and Ogunrinade B.I. (1980). Economic importance of bovine fascioliasis in Nigeria. Trop. Anim. Health Prod. 12(3):155-160.

29. Ojo S.A. (1996). A survey of pathological conditions in slaughtered goats at Zaira slaughter houses. In: Proceedings of the Third Biennial Conference of the African Small Ruminant Research Network UICC, Kampala, Uganda 5-9 December 1994. Edited by Lebbie S.H.B. and Kagwini E. http:www.fao.org/wairdocs/ilri/x5473b/x5473b13.htm.

30. Okoli I.C., Agoh E.C., Okoli G.C., Idemi G.C. and Umesiobi D.O. (2000). Bovine and caprine fasciolosis in Enugu State of Nigeria. Retrospective analysis of abattoir records (19931997) and six-month prevalence study. Bull. Anim. Health and Prod. Afr. 48: 7-11.

31. Opara M.N. (2005). Pathological conditions from abattoirs in Akwa Ibom state, Nigeria. Anim. Res. Int., 2(2):314-318.

32. Raji M.A., Salami S.O. and Ameh J.A. (2010). Pathological conditions and lesions observed in slaughtered cattle in Zaria abattoir. J. Clin. Pathol. Forensic Med., 1(2): $9-12$.

33. Schwabe C.V. (1984). Veterinary Medicine and Human Health. 3rd ed. Williams and Wilkins Publication, Baltimore.

34. Schweizer G., Plebani G.F., Braun U. (2003). Prevalence of Fasciola hepatica and Dicrocoelium dendriticum in the cow: inspection in an east Switzerland abattoir. Schweiz. Arch. Tierheilkd. 145:177-179.

35. Soulsby E.C. (1998). Helminthes, arthropods and protozoa of domesticated animals. Bailliere, Tindall and Easel Ltd, London. pp 465-469.

36. Swai E.S. and Ulicky E. (2009). An evaluation of the economic losses resulting from condemnation of cattle livers and carcass weight due to Fasciolosis: a case study from 
Hai town abattoir, Kilimanjaro region, Tanzania Livestock Research for Rural Development, 21(11): Article \#186. Retrieved May 27, 2011, from http://www.lrrd.org/ lrrd21/11/swai21186.htm.

37. Tanya V.N. (2004). "The contribution of animal and fisheries research to poverty alleviation in Cameroon" In: Proceedings of the 11th Annual Conference of Bioscience: Animal Production and Poverty Alleviation, F. T. Mbiapo, F.X. Etoa, et al., Eds., pp. 1-6, The Cameroon Bioscience Society, Yaounde, Cameroon, 10th edition.
38. Tijjani A.O., Musa H.I., Atsanda N.N. and Mamman B. (2010). Prevalence of hydatidosis in sheep and goats slaughtered at Damaturu, Yobe State, Nigeria. Nig. Vet. J. 31(1):71-75.

39. Woldemeskel M. (2000). Dermatophilosis: a threat to livestock production in Ethiopia. Dtsch Tierarztl Wochenschr. 107(4):144-6.

40. World Health Organization. (2004). Global TB control report: Nigerian annex. Geneva, Switzerland, WHO. http//www.who.int/tb/publications/global_report/2004. 